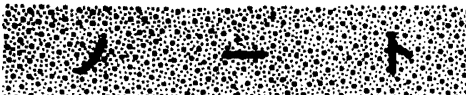

\%म $+\%+\%$

\title{
原子吸光法によるかん詰食品中の溶出スズに関する研究
}

(昭和 47 年 10 月 7 日受理)

$\begin{array}{llll}\text { 佐藤直樹* } & \text { 霍田克彦* } & \text { 鎌田 } & \text { 勲* } \\ & \text { 成田静一* } & \text { 虬川 } & \text { 宏* }\end{array}$

\section{Studies on Dissolved Tin in Canned Foods by Atomic Absorption Spectrophotometry}

\author{
Naoki SATO, Katsuhiko TSURUTA, Isao KAMADA, \\ Seiichi NARITA and Hiroshi ABUKAWA \\ (* Oshima Health Center: 12-12 Chitose-cho, Hakodate, Hokkaido)
}

\begin{abstract}
A simple method for determination of tin in a large number of canned foods were investigated by atomic absorption spectrophotometry with a three-slot burner and acetyleneair flame.

Samples were prepared from the foods mainly by extraction with hydrochloric acid and partially by the method of wet ashing.

Among various coexistent substances, an effect of concentration of sugar was investigated, and it was found that increase in concentration of sugar caused considerable decrease in absorbance.

Dissolved tin in syrups of canned foods was able to be determined sufficiently exactly by extraction with hydrochloric acid and standard addition method.

Dissolving of tin in canned foods proceeded after opening of the canned foods, and was essentially correlated with inside coating materials of cans.
\end{abstract}

(Received October 7, 1972)

\section{まえかiき}

かん詰食品中のスズの溶出量については清涼飲料水の みに $150 \mathrm{ppm}$ 以下と規定されているのみで他のかん詰 食品に対しては規制がなされていない現状にある. しか るに著者らが昨年から実施した食品検查でもパイナップ ル, アスパラガスかん詰（いずれもシロップ部分のみ測 定）の開かん直後で $150 \mathrm{ppm}$ をこえるスズが検出され た.

著者らはかん詰食品の溶出スズ量の害態を把握するた めの原子吸光法による簡便でかつ信頼度の高い分析方法

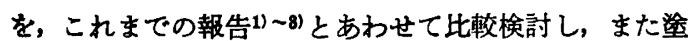
装の有無と溶出スズ量との関連等についても調べ, 若干 の知見を得たので報告する.
Table 1. Operating Condition for the Determination of Tin by Atomic Absorption Spectrophotometry (Instrument: HITACHI 208 type)

\begin{tabular}{l|l}
\hline Light source & $\begin{array}{c}\text { HITACHI Hollow Cathode } \\
\text { Lamp }\end{array}$ \\
Wavelength & Sn $2840 \AA$ \\
Lamp current & $15 \mathrm{~mA}$ \\
Air flow rate & $13 \mathrm{~L} / \mathrm{min}$. \\
\multicolumn{1}{c}{ pressure } & $1.8 \mathrm{~kg} / \mathrm{cm}^{2}$ \\
Acetylene flow rate & $3.5 \mathrm{~L} / \mathrm{min}^{\prime}$ \\
$\quad$ pressure & $0.5 \mathrm{~kg} / \mathrm{cm}^{2}$ \\
Burner & Three-slot burner
\end{tabular}

\footnotetext{
*北海道湾岛保线所：函馆市千嵅町 12-12
} 


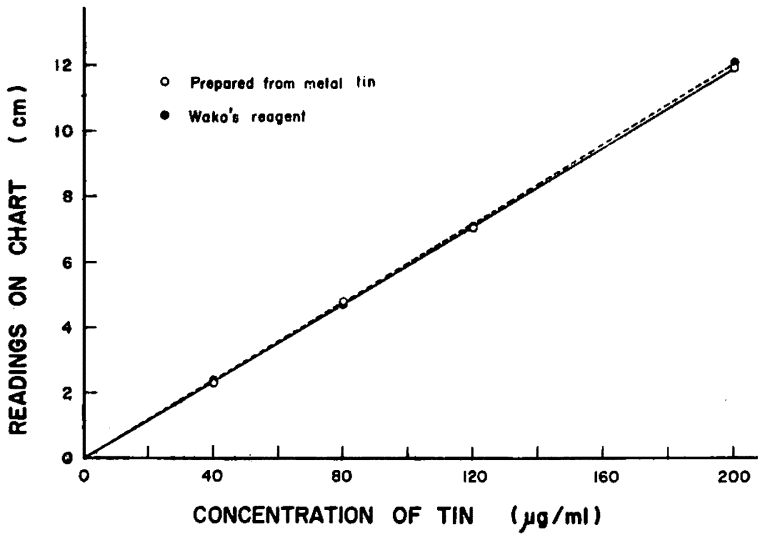

Fig. 1. Comparison of calibration curves for tin made from metal tin and Wako's reagents

Concentration of hydrochloric acid; $1.2 \mathrm{~N}$.

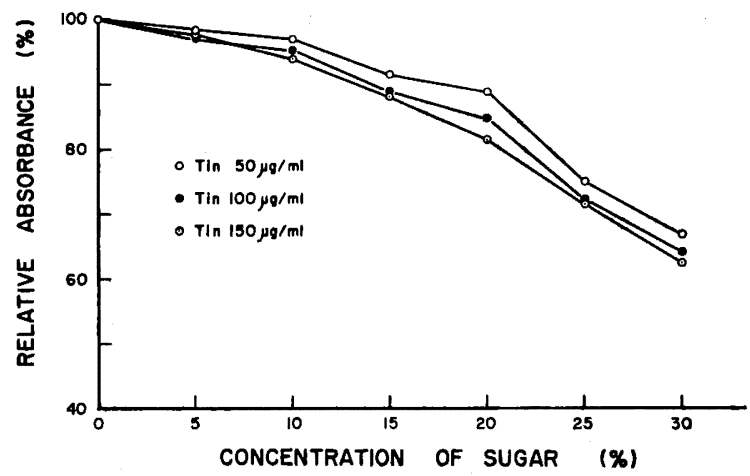

Fig. 2. Effect of concentration of sugar on tin determination

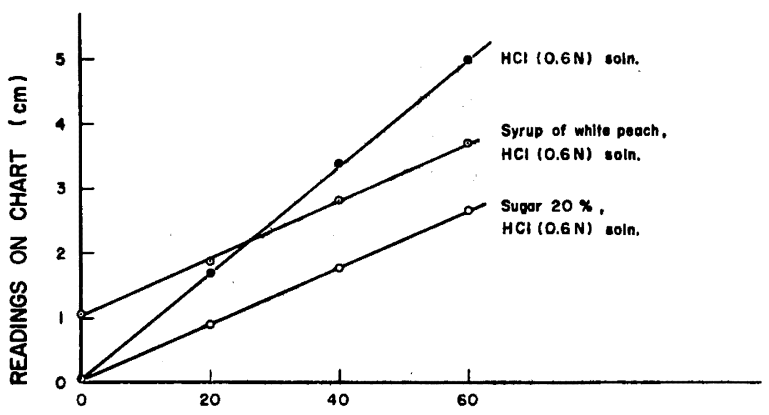

CONCENTRATION OF TIN IN PREPARED SAMPLES $(\mu \mathrm{g} / \mathrm{ml})$

Fig. 3. Calibration curves made by standard addition method

Concentration of sugar in syrup of white peach; approx. $20 \%$.
Table 2. Determination of Tin under Various Conditions for Extract Sample preparation: Direct filtration

(4-a)

A) Orange juice

\begin{tabular}{c|c|c}
$\begin{array}{c}\mathrm{HCl} \text { conc. } \\
(\mathrm{N})\end{array}$ & $\begin{array}{c}\text { Temp. } \\
\left({ }^{\circ} \mathrm{C}\right)\end{array}$ & $\begin{array}{c}\text { Tin content } \\
(\mu \mathrm{g} / \mathrm{ml})\end{array}$ \\
\hline 0.6 & 20 & 7 \\
0.6 & 37 & 7 \\
1.2 & 20 & 7 \\
1.2 & 37 & 7
\end{tabular}

B) Syrup of canned pineapple

\begin{tabular}{c|c|c|c}
$\begin{array}{c}\mathrm{HCl} \text { conc. } \\
(\mathrm{N})\end{array}$ & $\begin{array}{c}\text { Temp. } \\
\left({ }^{\circ} \mathrm{C}\right)\end{array}$ & \multicolumn{2}{|c}{ Tin content $(\mu \mathrm{g} / \mathrm{ml})$} \\
\cline { 2 - 3 } & $\begin{array}{c}\text { Standard } \\
\text { addition } \\
\text { method }\end{array}$ & $\begin{array}{c}\text { Calibration } \\
\text { plot method }\end{array}$ \\
\hline 0.6 & 20 & 74 & 64 \\
0.6 & 37 & 73 & - \\
1.2 & 20 & 71 & 65 \\
1.2 & 37 & 72 & -
\end{tabular}

実酸方法

1. 装

日立 208 型原子吸光分析計

光源ランプ：日立社製スズ中空陰極ランプ

然料：アセチレン, 助然剤として空気を使用. バーナー：スリースロットバーナー

2. 測定条件

測定は Table 1 に示す条件で行なった。

\section{3. 試験溶液の調製}

3-a. 塩酸抽出法（その 1)：開かん後のシロ ップ部分をろ過し（東洋滤紙 No. $5 \mathrm{~A}$, 以下寸べ て同じ口紙を使用)，ろ液 $5 \mathrm{ml} に 6 \mathrm{~N}$ 塩酸また は適当量のスズ標準溶液を添加した $6 \mathrm{~N}$ 塩醉を 1 または $2 \mathrm{ml}$, さらに水を加え $10 \mathrm{ml}$ とする。 これにより最終塩酸菨度は $0.6 \mathrm{~N}$ または $1.2 \mathrm{~N}$ と

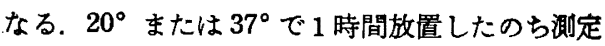
した.

3-b. 塩酸抽出法（その 2)：開かん後のシ口 ップ部分 $1 \mathrm{ml} に 6 \mathrm{~N}$ 塩酸または適当量のスズ標 準溶液を添加した $6 \mathrm{~N}$ 塩酸を 1 または $2 \mathrm{ml}$ 加え $37^{\circ} ， 1$ 時間放置後水を加え $10 \mathrm{ml}$ としたのちろ 過しただちに測定した。

3-c. 湿式灰化法: シロップは各 $20 \mathrm{ml}$, 固形 物は各 $20 \mathrm{~g}$ (湿重量)をケルダールフラスコにと り水 $30 \mathrm{ml}$, 硝酸 $30 \mathrm{ml}$, 硫酸 $10 \mathrm{ml}$ を加文石綿 上直火でかっ色の煙の発生がおかるまで加熱す る.フラスコ内溶液が無色〜淡黄色澄明にならな 
Table 3. Determination of Tin in Samples Prepared by Three Methods

The syrup of each sample was analysed. Assay was made on samples elapsed for 48 hours after opening of can.

\begin{tabular}{c|c|c|c}
$\begin{array}{c}\text { Methods for } \\
\text { extraction }\end{array}$ & \multicolumn{3}{|c}{ Tin content $(\mu \mathrm{g} / \mathrm{ml})$} \\
\cline { 2 - 4 } Sample & a) Direct filtration & b) Direct extraction & c) Wet ashing \\
\hline Pineapple & 280 & 285 & 265 \\
Asparagus & 114 & 125 & 110 \\
White peach & 194 & 195 & 190
\end{tabular}

い時は泠後硝酸 $10 \mathrm{ml}$ を加之加熱し，無色〜淡黄色澄明 な液になるまでこの追加をくりかえす，澄明な分解液は 泠後水 $50 \mathrm{ml}$ 打よび飽和シュウ酸アンモニウム溶液 25 $\mathrm{ml}$ を加え 白煙が発生するまで加熱する. 冷後水を加え て $100 \mathrm{ml}$ とする. なおそ後の試験溶液の処理は a の 方法により (ろ過不要)， $37^{\circ} ， 1$ 時間放置後測定した. 別に試料をもちいないで同様に操作し空試験溶液とし た.

\section{4. スス標準溶液}

4-a. 和光純薬製原子吸光用スズ標準溶液 $(1 \mathrm{mg} /$ $\mathrm{ml})$.

4-b. 金属スズ 1 に濃塩酸 $60 \mathrm{ml}$ を加え時計皿でおお い水浴上で加温溶解し, 冷後 $1 \mathrm{~N}$ 塩酸を加え $1000 \mathrm{ml}$ とした。この溶液 $1 \mathrm{ml}$ 中には $1 \mathrm{mg}$ のスズが含まれる.

\section{5. 検量線の作製}

4-a, 4-b のスズ標準溶液 $0.4 \sim 2.0 \mathrm{ml}$ をとり， $6 \mathrm{~N}$ 塩酸 1.6 0 ml を加え, さらに水を加えて全量を $10 \mathrm{ml}$ とした溶液について試料の場合と同様に原子吸光分析を 行ない検量線を作製したところ，Fig. 1 に示すように 両者はまったく一致した.

以後の実験にはすべて 4-a の標準溶液を使用した。 内そう法によりスズ含量を求める場合はこの検量線によ った.

\section{結果および考察}

\section{1. 精婊度の影䇾と標準添加法}

適当量のスズ標準溶液を添加した各種濃度のショ糖溶 液について，3-a の方法で試験溶液を調製し測定した. 果害かん詰の糖濃度は高いもので $20 \%$ にも達するが， 内そら法によりスズ含量を求める場合糖濃度が高くなる 程回收率が低くなることが報告されている2，8)。本実験 に打いても Fig. 2 にみられるように糖濃度の影響を大 きくらけることが知られた。

なおスズ含量が低い場合 $(0 \sim 10 \mu \mathrm{g} / \mathrm{ml})$ についても 同様な㑯向になることが確かめられた。

糖20\%およびモモシロップ部分（糖濃度約 $20 \%)$ 試料 に, スズの最終濃度 $20,40,60 \mu \mathrm{g} / \mathrm{ml}$ になるようにス ズ票準溶液を添加した場合の検量線を Fig. 3 に示す. 糖の影響による感度の低下は著しいが，測定値は正し
く直線上にあり，糖溶液に対するものは 0 点を通過する ので標準添加法によれば, ジュースまたはシロップ部分 の試料に対し直接原子吸光光度法が応用でさるはずであ る. 従って, 以下の実験では特に記載のない限りすべて 標淮添加法によった。

\section{2. 塩酸住度および抽出温度の影蔀}

オレンジショュース，ハイナップルかん詰シロップ部分 について塩酸濃度および抽出温度の影響を調べた。試験 溶液の調製は 3-a によった.

この結果, Table 2 に示すように, 塩酸濃度 $0.6 \mathrm{~N}$

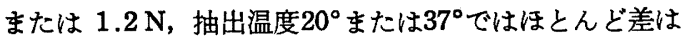
みられなかった。同様に 4-bについても検討したが 4-a

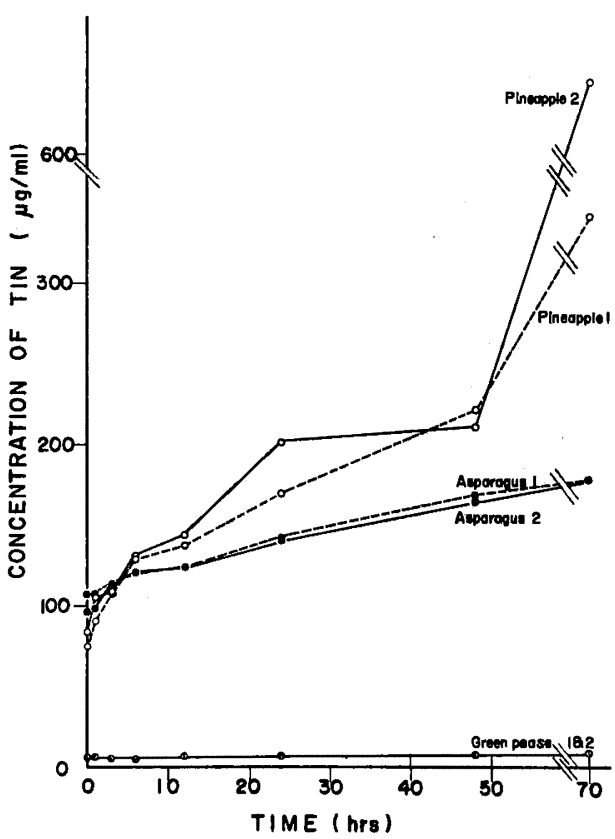

Fig. 4. Change of tin content after opening of canned foods

Only syrup was analysed after being stored at $5^{\circ} \mathrm{C}$ after opening of canned foods. 
Table 4. Change of Tin Content after Opening of Canned Foods Syrup was analysed by direct extraction method (b), and solids by wet ashing method (c). Stored at $5^{\circ} \mathrm{C}$ after opening of canned foods.

\begin{tabular}{|c|c|c|c|c|c|c|c|c|c|c|c|c|c|c|c|}
\hline & \multicolumn{14}{|c|}{ Tin content } \\
\hline & & \multicolumn{7}{|c|}{ Syrup $(\mu \mathrm{g} / \mathrm{ml})$} & \multicolumn{7}{|c|}{ Solids $(\mu \mathrm{g} / \mathrm{g})$} \\
\hline & & \multicolumn{7}{|c|}{ Time (hrs) } & \multicolumn{7}{|c|}{ Time (hrs) } \\
\hline & & 0 & 3 & 6 & 12 & 24 & 48 & 72 & 0 & 3 & 6 & 12 & 24 & 48 & 72 \\
\hline Pineapple & 1 & 83 & 107 & 141 & 150 & 166 & 220 & 232 & 58 & 58 & 74 & 99 & 116 & 147 & 187 \\
\hline Pineapple & 2 & 80 & 100 & 131 & 155 & 158 & 235 & 288 & 63 & 68 & 68 & 80 & 100 & 132 & 167 \\
\hline White peach & 1 & 25 & 31 & 57 & 57 & 58 & 89 & 96 & 27 & 32 & 37 & 39 & 64 & 93 & 97 \\
\hline White peach & 2 & 65 & 80 & 115 & 120 & 135 & 205 & 205 & 91 & 95 & 96 & 120 & 134 & 148 & 180 \\
\hline
\end{tabular}

とほとんど同じ傾向がみられた。

\section{3. 試駼溶湤調䌘法による影零}

ハイナップル，アスハラガス，モモかん詰のシャッブ 部分について試験溶液調製法による影響を調べた。

Table 3 にみられるように塩酸抽出法（aおよび b) に比較して湿式灰化法によった場合やや低い値になった がこれは湿式灰化操作に基つく損失に基因するものと推 定される.この実験により標準添加法によれば直接抽出 法（またはろ過直接抽出法）によって十分な回収率が得 られることが明らかである.

\section{4. 闒かん後のスス含早の程時变化}

開かん後そのままの状態で5゚に保存し適当な時間ごと に分取した，グリンピース（完全望装， $\mathrm{pH} \mathrm{6.0)，アス}$ パラガス（上下塗装・側面無淘装, $\mathrm{pH} 5.5$ ), パイナッ プル（無塗装, $\mathrm{pH}$ 3.7) 各 2 かんのシロップ部分につ

いて 3-a により試験溶液を調製し測定した。

その結果を Fig. 4 に示すがパイナップルかん詰につ いてスズの異常溶出現象がみられた。

同様の実験をパイナップル（無塗装, $\mathrm{pH} 3.7$ ), モモ （上下塗装・侧面無塗装， $\mathrm{pH} 3.8 ）$ 各 2 かんのシロッ プ，固形物についてさらに行なった，試験溶液の調製は シロップは 3-b, 固形物は3-cによった. 結果は Table 4 に示す.

開かん後のスズ含量の変化と塗装の有無との関連につ いて Fig. 4 と Table 4 を比較してみるとほぼ類似の 傾向がみられる.これらの結果から開かん後のスズ含量
の增加はかん詰中の食品の種類によって著しい差はある だろらが，塗装の有無がもっとも重要な要因と考えられ る.

\section{要 的}

果汁，果実そ菜かん詰について原子吸光法により溶出 スズ量を分析した，簡便に定量するため主としてシロッ プ部分を直接法により分析したが一部湿式灰化法にもよ った。

しかしシロップ部分については灰化処理を行なわなく ても標準添加法によって十分に正確な測定値が得られる ものと思われる.

直接法による試験溶液の調製では糖の影慗が著しい が，標準添加法により十分に正確な值が得られ，簡便法 としては有用であろう.

開かん後のスズ含量の増加はかん詰食品の種類によっ て著しい差があるが，塗装の有無がもっとも重要な要因 と考えられる.

本稿の要旨は日本食品衛生学会第24回学術講演会（昭 和47年10月，秋田）に拈いて報告した。

文献

1) 岩本喜伴, 前田酥子, 堸尾嘉友：食衛誌。11, 183 (1970).

2）鈴木健次郎, 森 光国: 同上. 12，4 (1971).

3) 白石慶子, 慕原由算, 末永泉二：同上. 13,97 (1972). 